\title{
Identification of seed proteins associated with resistance to pre-harvested aflatoxin contamination in peanut (Arachis hypogaea L)
}

Tong Wang ${ }^{1,2}$, Erhua Zhang ${ }^{2}$, Xiaoping Chen ${ }^{2}$, Ling Li ${ }^{1}$, Xuanqiang Liang ${ }^{1,2^{*}}$

\begin{abstract}
Background: Pre-harvest infection of peanuts by Aspergillus flavus and subsequent aflatoxin contamination is one of the food safety factors that most severely impair peanut productivity and human and animal health, especially in arid and semi-arid tropical areas. Some peanut cultivars with natural pre-harvest resistance to aflatoxin contamination have been identified through field screening. However, little is known about the resistance mechanism, which has slowed the incorporation of resistance into cultivars with commercially acceptable genetic background. Therefore, it is necessary to identify resistance-associated proteins, and then to recognize candidate resistance genes potentially underlying the resistance mechanism.

Results: The objective of this study was to identify resistance-associated proteins in response to $A$. flavus infection under drought stress using two-dimensional electrophoresis with mass spectrometry. To identify proteins involved in the resistance to pre-harvest aflatoxin contamination, we compared the differential expression profiles of seed proteins between a resistant cultivar (YJ-1) and a susceptible cultivar (Yueyou 7) under well-watered condition, drought stress, and A. flavus infection with drought stress. A total of 29 spots showed differential expression between resistant and susceptible cultivars in response to A. flavus attack under drought stress. Among these spots, 12 protein spots that consistently exhibited an altered expression were screened by Image Master 5.0 software and successfully identified by MALDI-TOF MS. Five protein spots, including Oso7g0179400, Pll protein, CDK1, Oxalate oxidase, SAP domain-containing protein, were uniquely expressed in the resistant cultivar. Six protein spots including low molecular weight heat shock protein precursor, RIO kinase, L-ascorbate peroxidase, iso-Ara h3, $50 \mathrm{~S}$ ribosomal protein L22 and putative $30 \mathrm{~S}$ ribosomal S9 were significantly up-regulated in the resistant cultivar challenged by A. flavus under drought stress. A significant decrease or down regulation of trypsin inhibitor caused by $A$. flavus in the resistant cultivar was also observed. In addition, variations in protein expression patterns for resistant and susceptible cultivars were further validated by real time RT-PCR analysis.
\end{abstract}

Conclusion: In summary, this study provides new insights into understanding of the molecular mechanism of resistance to pre-harvest aflatoxin contamination in peanut, and will help to develop peanut varieties with resistance to pre-harvested aflatoxin contamination.

\section{Background}

Peanut (Arachis hypogaea L.) is one of most important and widespread oil crops. One of the major problems in peanut production worldwide is aflatoxin contamination, which is of great concern in peanut as this toxin can cause teratogenic and carcinogenic effects in animal and

\footnotetext{
* Correspondence: Liang-804@163.com

'Gguangdong Key Lab of Biotechnology for Plant Development, College of Life Science, South China Normal University, Guangzhou 510631, China Full list of author information is available at the end of the article
}

human. Infection of peanut by Aspergillus flavus occurs not only in post-harvest but also in pre-harvest conditions [1-3]. Several biotic (soil-born insects) and abiotic (drought and high temperature) factors are known to affect pre-harvest aflatoxin contamination, while the late season drought (20-40 days before harvest) which predispose peanut to aflatoxin contamination [4-9] is more important in the semi-arid tropics [10,11]. Irrigation in late season can reduce peanut pre-harvest aflatoxin contamination, but this cultural practice seems to be 
impractical in some areas, especially in semi-arid and arid areas. Enhancing host plant resistance to preharvest $A$. flavus invasion and aflatoxin contamination is considered to be the most cost-effective control measure. In the past decades, peanut cultivars with natural pre-harvest resistance to aflatoxin production have been identified through field screening [12-21]. However, the agronomic traits of these varieties have been very poor for the direct commercial utility. The progress in transferring the resistance genes from these resistant lines into commercial cultivars has been slow, due to lack of understanding of the resistance mechanism and markers associated with resistance [22].

Although drought stress is known to predispose peanut to aflatoxin contamination [4-9], limited researches were reported on the mechanism of late season drought stress aggravating the $A$. flavus infection. Dorner et al (1989) [23] observed that drought stress could decrease the capacity of peanut seeds to produce phytoalexins, and thus resulted in higher aflatoxin contamination. The active water of seeds is the most important factor controlling the capacity of seeds to produce phytoalexins [23,24]. Luo et al (2005) [25] used a microarray of 400 unigenes to investigate the up/down regulated gene profiles in peanut cultivar A13, which is drought tolerant and resistant to pre-harvest aflatoxin contamination, and identified 25 unigenes that were potentially associated with drought tolerance or that responded to $A$. parasiticus challenge. Nevertheless, the significance of these unigenes in pre-harvest infection of peanut pods by Aspergillus is incomplete without knowledge of their functions. Studies to understand host resistance mechanisms in maize and peanut against $A$. flavus infection and aflatoxin contamination indicate that proteins are a major factor contributing to kernel resistance [1,2,26,27].

Proteins serve as the bridge between genetic information encoded in the genome and the phenotype. Proteomics analysis reveals the plasticity of gene expression as it allows global analysis of gene products and physiological states of plant under particular conditions. The objectives of this research were to: (1) compare the differential expression of proteins of resistant and susceptible peanut cultivars in response to A. flavus challenge under drought stress; (2) identify seed proteins associated with resistance to pre-harvest aflatoxin contamination in peanut. In this study, a total of 28 differentially expressed proteins were identified and 12 proteins associated with pre-harvested aflatoxin contamination were further characterized by MALDI-TOF MS and their expression profiles were validated by real-time RT-PCR. The identification of these potential proteins associated with the aflatoxin resistance in peanut could be useful in programmes on developing peanut varieties with resistant to pre-harvest aflatoxin contamination.

\section{Results}

Aflatoxin accumulation analysis in seeds of resistant and susceptible cultivars

Seed aflatoxin B1 levels from the resistant cultivar (YJ-1) and susceptible cultivars (Yueyou 7) had baseline levels (approximately $1 \mathrm{ppb}$ ) under well-watered conditions, and no difference between the two cultivars was found (Table 1). Under drought stress conditions, the seed aflatoxin B1 level in both YJ-1 and Yueyou 7 increased. The level of aflatoxin B1 increased to $22 \mathrm{ppb}$ and 162 ppb in YJ-1 and Yueyou 7 respectively under drought stress. After artificial inoculation treatment with $A$. flavus under drought stress, the aflatoxin B1 level in seeds of the infected cultivar YJ-1 increased to $135 \mathrm{ppb}$, whereas the level in the infected cultivar Yueyou 7 increased to $1901 \mathrm{ppb}$, suggesting that aflatoxin B1 accumulation in the susceptible cultivar Yueyou 7 was around 14-fold compared to the resistant cultivar YJ-1. YJ-1 exhibited a significant level of resistance to preharvest aflatoxin contamination. These results are in agreement with several earlier reports of resistance in peanut [28].

Comparison of seed proteomic profiles between resistant and susceptible cultivars under $A$. flavus challenge and drought stress

To investigate the seed protein profiles, we carried out 2-DE analysis of the proteins from six sample groups as described in the Methods section. Due to the lower resolution at the anodal and cathodal ends of the first dimension tube gels, only the gel region where the pI ranged from 5 to 8 was further analyzed. For each treatment, 2-DE gels were run in three replicates. More than 500 protein spots were repeatedly detected on Coomassie brilliant blue G-250 -stained gels using Image Master 5.0 software across all the samples (Figure 1) and the reproducibility of all gels were over $95.0 \%$ (Additional file 1).

A comparison of 2 -DE images revealed that there were both qualitative and quantitative differences in resistant or susceptible cultivars under the three treatment conditions (Additional file 2). Under the well-

Table 1 Mean aflatoxin B1 contamination of resistant and susceptible cultivars planted at different condition in 2008/2009 season at Guangzhou, China

\begin{tabular}{ccc}
\hline Treatments & \multicolumn{2}{c}{$\begin{array}{c}\text { Mean aflatoxin B1 contamination } \\
\text { (ppb) }\end{array}$} \\
\cline { 2 - 3 } & $\begin{array}{c}\text { Resistant } \\
\text { cultivar YJ-1 }\end{array}$ & $\begin{array}{c}\text { Susceptible cultivar } \\
\text { Yueyou7 }\end{array}$ \\
\hline Well-watered condition & 1.2 & 1.3 \\
Drought-stress & 22 & 162 \\
A. flavus inoculation under & 135 & 1901 \\
drought stress & & \\
\hline
\end{tabular}




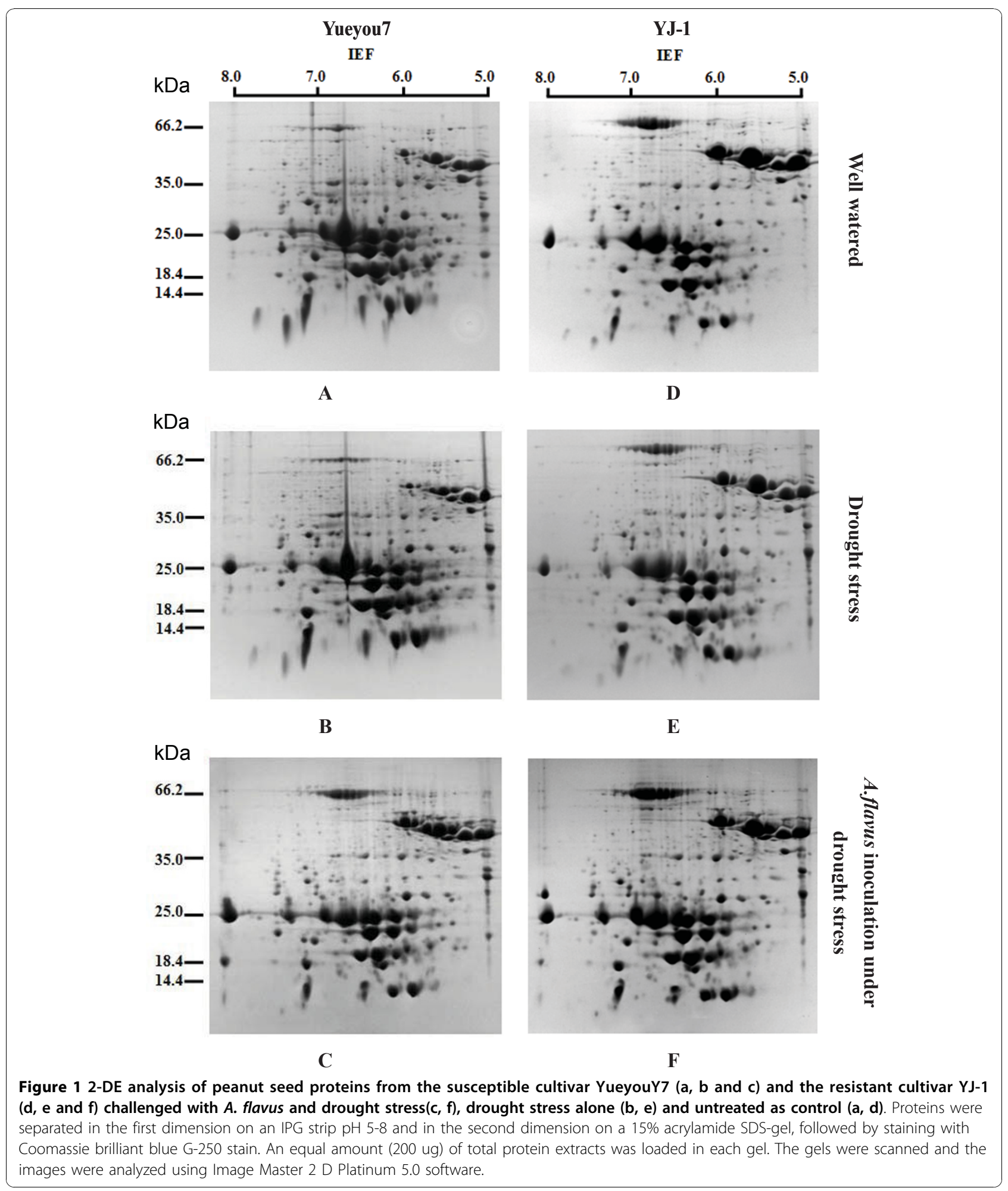

watered condition, the 2-DE gel of resistant cultivar YJ-1 showed 542 high quality spots (Additional file 1), while 11 unique, 12 up-regulated, 6 down-regulated and 6 disappeared spots were induced by drought stress, 17 unique, 15 up-regulated, 5 down- regulated and 7 disappeared spots were induced by $A$. flavus infection under drought stress (Additional file 2). The 2-DE protein profiles of the susceptible cultivar (Yueyou 7) showed a similar differential expression pattern responsive to drought stress and $A$. flavus infection, but the 
number of differentially expressed spots was less than that of the resistant cultivar (YJ-1). Five unique, 10 upregulated, 5 down-regulated and 3 disappeared spots were induced by drought stress, while 12 unique, 11 upregulated, 8 down-regulated and 4 disappeared spots were induced by $A$. flavus infection under drought stress in susceptible cultivar Yueyou 7 (Additional file 2).

To investigate the host proteins responsive to $A$. flavus infection, a comparison was conducted with $2-\mathrm{DE}$ images of total seed proteins from the resistant cultivar (YJ-1) and the susceptible cultivar (Yueyou 7) with A. flavus infection under drought stress (Table 2). About 29 spots that showed differential expression in all analytical gels under $A$. flavus attack were identified. Among those, 12 protein spots that consistently exhibited unique, increased or decreased in abundance and at least four fold differences in spot intensity in gel of resistant cultivar (YJ-1) with A. flavus infection under drought stress, compared with gel of the susceptible cultivar (YY-7) received the same treatment. Of these, five protein spots (S6256, S6258, S6264, S6278, and S6503) with unique expression, six protein spots (S1368, S1521, S1419, S1429, S16169 and S6107) with an up-regulated trend, and one protein spots (S1314) with a down-regulated trend in the resistant cultivar (YJ-1) by $A$. flavus infection under drought stress were selected for MS analysis. The enlargements of the 12 differentially expressed proteins were shown in Figure 2.

\section{Identification of the differentially expressed proteins related to resistance to pre-harvest aflatoxin contamination}

All of the twelve differentially expressed proteins were excised and analyzed by MALDI-TOF-MS to identify their putative functions. After searching against the green plant protein database in NCBI, all these protein spots were successfully identified by PMF analysis and matched known plant proteins. Those proteins and their annotated functions are listed in Table 3. Since there are relatively few known

Table 2 Differential expression spots of resistant cultivar YJ-1 compared to susceptible cultivar Yueyyou7 in response to $A$. flavus invasion under drought stress condition

\begin{tabular}{lcc}
\hline & $\begin{array}{c}\text { Differential expression spots in } \\
\text { YJ-1 compared to Yueyou 7 }\end{array}$ & $\begin{array}{c}\text { Selected for } \\
\text { MS analysis }\end{array}$ \\
\hline $\begin{array}{l}\text { No. of unique } \\
\text { express spot }\end{array}$ & 8 & 6 \\
$\begin{array}{l}\text { No. of up } \\
\text { regulated spot }\end{array}$ & 10 & 5 \\
$\begin{array}{l}\text { No. of down } \\
\text { regulated spot } \\
\text { No. of miss }\end{array}$ & 7 & 1 \\
spot & 4 & \\
Total & 29 & 12 \\
\hline
\end{tabular}

peanut proteins and genomic sequences available, only three proteins matched peanut proteins. Among the twelve selected proteins, four were related to stress response: Low molecular weight heat shock protein precursor (S6107), Oxalate oxidase (S6278), Trypsin inhibitor (S1314) and L-ascorbate peroxidase 1(S1521). Os07g0179400 (S6256), CDKD1 (S6264) and RIO kinase (S1368) were signaling components. SAP domain-containing protein (S6503), $50 \mathrm{~S}$ ribosomal protein L22 (S1429) and putative $30 \mathrm{~S}$ ribosomal protein S9 (S6169) were related to regulation of transcription. PII protein (S6258) and iso-Ara h3 (S1419) were storage protein.

\section{Gene Transcription Profile Analysis by real time RT-PCR}

To validate the expression of the twelve identified proteins at transcription level, total RNAs from six samples (see the Methods section) were extracted and analyzed by real time RT-PCR. The primer pairs used for real time RT-PCR were designed based on nucleotide sequences in NCBI databases and shown in Table 3 the actin gene was chosen as internal control. Figure 3 shows the expression patterns of the twelve genes in the resistant cultivar (YJ-1) and the susceptible cultivar (Yueyou7) under well-watered (control), drought stress and $A$. flavus infection accompanied with drought stress on the $50^{\text {th }}$ days after treatments. The results demonstrated that, of the five genes identified as the unique expressed group (S6256, S6258, S6264, S6278, and S6503), S6258 and S6278 showed higher expression levels in the cv. YJ-1 than in the cv. Yueyou7, S6264 showed similar and the remaining two showed lower. Of the six proteins identified as the up-regulated group (S1368, S1521, S1419, S1429, S6107 and S6169), four genes (S1521, S1419, S1429, S6169) showed higher expression levels in the resistant cultivar with $A$. flavus infection under drought stress. In contrast, two genes (S1368 and S6107) showed no correlation between mRNA and protein expression levels. One gene (S1314) identified in the down-regulated group, showed the identical level of transcript abundance in both resistant and susceptible cultivars with $A$. flavus infection plus drought stress.

\section{Discussion}

In this study, proteins showing differentially expressed profiles in the resistant and susceptible cultivars with A. flavus infection under drought stress were identified by using a proteomic approach. Around 550 protein spots identified for quantitative analyses of differentially regulated proteins responsive to $A$. falvus attack, and the number of protein spots was more than that in earlier reports by Liang et al (2006b) [29] and Kottapalli et al (2008) [30]. We have identified 12 protein spots which significantly increased or decreased in response to 


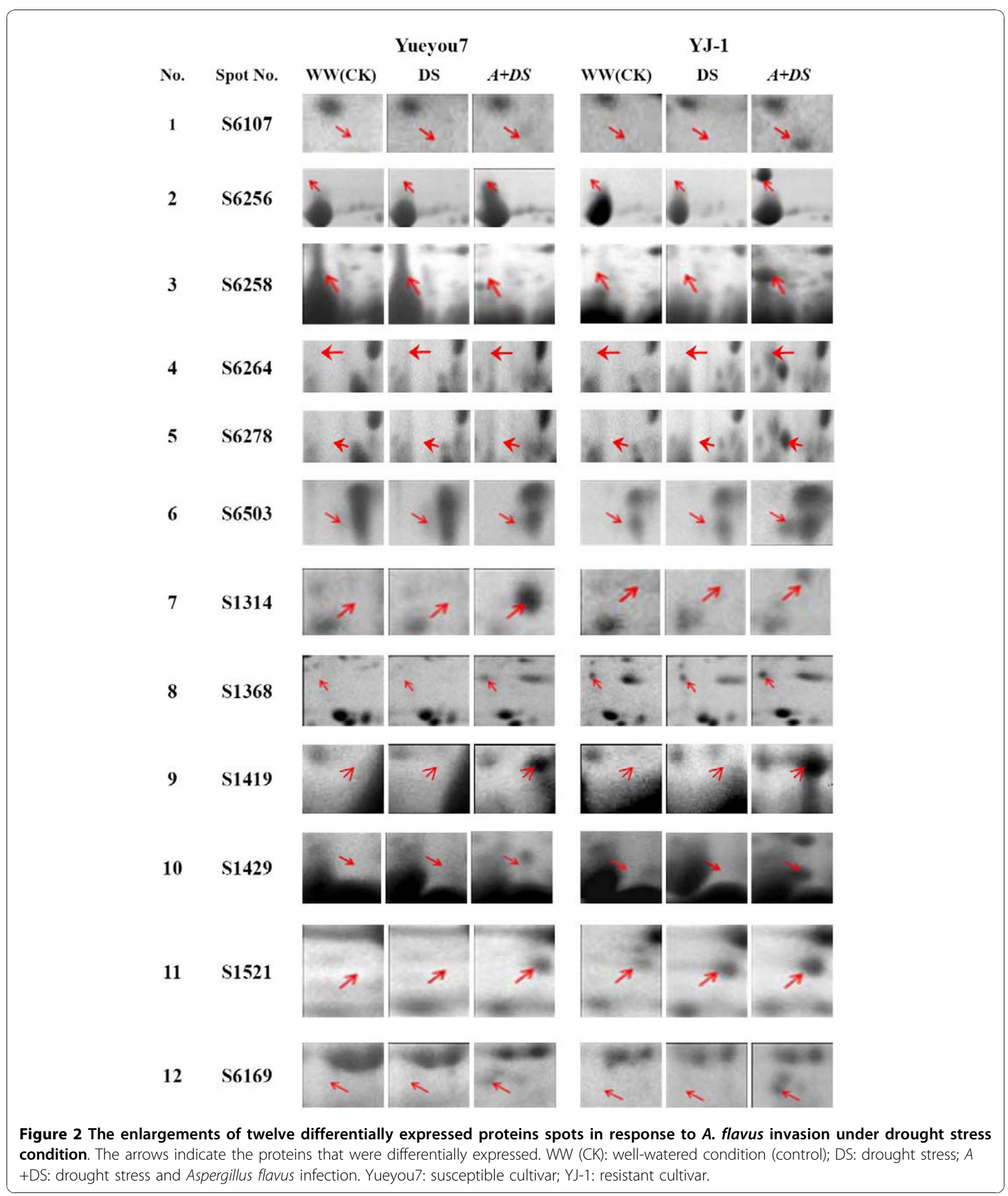

A. flavus infection under drought stress in resistant cultivar (YJ-1) versus susceptible cultivar. These proteins could be divided into four functional groups including defense response, signaling components, regulation of transcription and storage protein.
Os07g0179400 (s6256) with transferase and kinase activity is a key protein in biosynthetic process [31]. CDKD1 (s6264) is involved in the phosphorylation of proteins and regulation of cell cycle [32]. Oxalate oxidase (s6278) belongs to the germin-like family of proteins and catalyzes 
Table 3 Differentially expressed proteins of peanut seed under infection by A. flavus identified by MALDI-TOF MS*

\begin{tabular}{|c|c|c|c|c|c|c|c|c|}
\hline No. $^{a}$ & Accession No. & Homologous protein & Organism & $\begin{array}{l}\text { Description of potential } \\
\text { function }\end{array}$ & $\begin{array}{l}\text { Theo. Mr } \\
(\mathrm{kD}) / \mathrm{pl}^{\mathbf{b}}\end{array}$ & $\mathrm{PM}^{\mathrm{c}}$ & $\begin{array}{l}\text { SC } \\
(\%)^{d}\end{array}$ & $\begin{array}{c}\text { Protein } \\
\text { Score } \\
\end{array}$ \\
\hline S6107 & AAC12279.1 & $\begin{array}{l}\text { Low molecular weight heat shock } \\
\text { protein precursor }\end{array}$ & Zea mays & Stress response & $23.8 / 6.5$ & 10 & 37.1 & 55 \\
\hline S6256 & NP_001059035.1 & Os07g0179400 & Oryza sativa & Signaling components & 20.0/5.1 & 9 & 36.36 & 58 \\
\hline S6258 & AAC78332.1 & PII protein & $\begin{array}{l}\text { Arabidopsis } \\
\text { thaliana }\end{array}$ & Unclassified & $21.7 / 8.9$ & 10 & 38.1 & 60 \\
\hline S6264 & NP_177510.1 & CDKD1 & $\begin{array}{l}\text { Arabidopsis } \\
\text { thaliana }\end{array}$ & Signaling components & $45.1 / 9.4$ & 16 & 27.1 & 76 \\
\hline S6278 & ABS86850.1 & Oxalate oxidase & $\begin{array}{l}\text { Arachis } \\
\text { hypogaea }\end{array}$ & Defense response & 23.1/7.7 & 14 & 23 & 80 \\
\hline S6503 & NP_201151.2 & SAP domain-containing protein & $\begin{array}{l}\text { Arabidopsis } \\
\text { thaliana }\end{array}$ & Regulation of transcription & $17.5 / 9.8$ & 12 & 39.5 & 70 \\
\hline S1314 & AAM93157.1 & Trypsin inhibitor & $\begin{array}{l}\text { Arachis } \\
\text { hypogaea }\end{array}$ & Defense response & $25.5 / 6.7$ & 10 & 37.9 & 81 \\
\hline S1368 & BAD12556.1 & RIO kinase & $\begin{array}{l}\text { Nicotiana } \\
\text { tabacum }\end{array}$ & Signaling components & $66.6 / 5.5$ & 18 & 23.3 & 66 \\
\hline S1419 & ABI17154.1 & Iso-Ara h3 & $\begin{array}{l}\text { Arachis } \\
\text { hypogaea }\end{array}$ & $\begin{array}{l}\text { Unclassified, storage } \\
\text { protein }\end{array}$ & $58.2 / 5.4$ & 10 & 24.8 & 96 \\
\hline S1429 & P49163 & 50 S ribosomal protein L22 & $\begin{array}{l}\text { Medicago } \\
\text { sativa }\end{array}$ & Regulation of transcription & 21.8/10.3 & 12 & 27.5 & 73 \\
\hline S1521 & Q05431 & L-ascorbate peroxidase 1 & $\begin{array}{l}\text { Arabidopsis } \\
\text { thaliana }\end{array}$ & Defense response & 27.5/5.7 & 10 & 25.6 & 56 \\
\hline 56169 & BAC81159.1 & Putative $30 \mathrm{~S}$ ribosomal protein S9 & Oryza sativa & Regulation of transcription & $45.0 / 5.5$ & 16 & 25.5 & 71 \\
\hline
\end{tabular}

a: Spot number; b: Theoretical molecular weight/isoelectric point; c: Number of matched peptides; d: Sequence coverage.

the degradation of oxalic acid to produce carbon dioxide and hydrogen peroxide [33]. Reports of oxalate oxidase activity in response to pathogen attack have received considerable attention as it possibly plays a role in plant defense [34-37]. In plants, PII protein (s6258) is a nuclearencoded plastid protein [38] and can be involved in the regulation of nitrogen metabolism [39]. SAP domaincontaining protein (s6503) was a DNA binding protein and its physiological roles remain to be unknown. In this study, these five proteins had unique expression in resistant cultivars and completely absent in the susceptible cultivar in response to $A$. flavus infection under drought stress, or under only drought stress condition. These proteins were, therefore, considered to be encoded by candidate resistance-related genes potentially involved in resistance to preharvest aflatoxin contamination.

Heat shock proteins (s6107), $50 \mathrm{~s}$ ribosomal protein (s1429), $30 \mathrm{~s}$ ribosomal protein (s6169) and iso-ara h3 (s1419) were up-regulated in both cultivars only in A. flavus infection under drought stress condition, but the expression level in the resistant cultivar was higher than in susceptible cultivar. Heat shock proteins (HSP) are the most well-known stress related proteins in plants which are induced in response to a number of different stresses. HSP can play a role as chaperons which are involved in correct folding of proteins and protect them from denaturing under stress condition [40]. In this study, HSP proteins could only be observed in peanut seeds upon $A$. flavus attack under drought conditions. This result was contradictive with those of Chen et al (2002, 2007) $[41,26]$, in which they reported that HSP proteins were constitutively expressed and up-regulated in resistant maize lines versus susceptible lines [26,41]. Both $50 \mathrm{~S}$ ribosomal protein (s1429) and putative $30 \mathrm{~S}$ ribosomal protein (s6169) are structural constituents of ribosome with RNA binding function, and play essential roles in translation processes [42]. The transcripts of ribosomal proteins in leaves of Arabidopsis plants were up-regulated under both drought and heat stress conditions [43]. The significant up-regulation of two ribosomal proteins suggested that one of the major effects of pre-harvest A. flavus infection in peanut is imposed on protein synthesis. Iso-Ara h3 (s1419), a peanut seed storage protein, shows significant homology to known peanut allergen, Arah3 [29]. The significant increase of iso-ara h3 in resistant cultivar compared with susceptible cultivar under A. flavus infection showed that iso-ara 3 (s1419) might be related to pre-harvest aflatoxin contamination.

$\mathrm{L}$-ascorbate peroxidase (s1521) is a stress-responsive protein [44], and is involved in the metabolism of $\mathrm{H}_{2} \mathrm{O}_{2}$ in higher plants [45]. Previous reports on peanut [24] and maize [26] showed L-ascorbate peroxidase were up-regulated by both $A$. parasticus and drought stress. RIO kinase (s1368) has kinase catalytic activity and is involved in ATP binding $[46,47]$. In this study, L-ascorbate peroxidase (s1521) and RIO kinase (s1368) were detected only in the resistant cultivar under well-watered conditions, and were up-regulated under drought stress conditions and $A$. flavus 

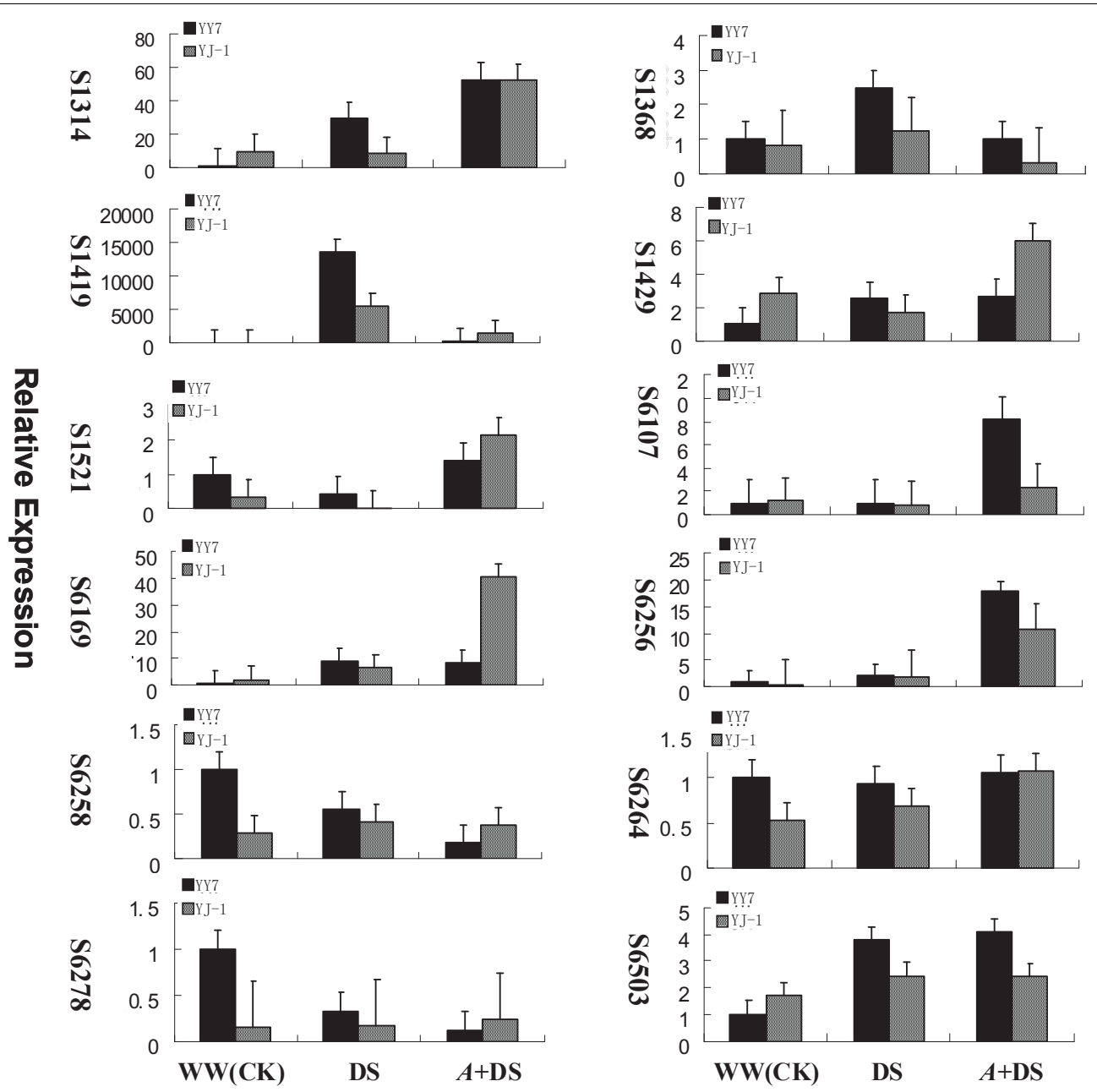

Figure 3 Real time RT-PCR analysis on mRNA transcription of the differentially expressed proteins in response to $A$. flavus invasion under drought stress condition. Total RNA were isolated from the seeds of resistant (YJ-1) and susceptible (Yueyou7, YY7) cultivar at 50 days post-treatments. Twelve genes were selected for real time RT-PCR analysis to study the relationship between protein expression and gene transcription and the expression levels normalized using actin gene as the internal control. The expression of these genes in Yueyou 7 under well-watered conditions was used as the target calibrator. Real-time PCR analyses were performed based on three replicates.

attack under drought stress conditions. In the susceptible cultivar, however, the two proteins were up-regulated only under A. flavus attack accompanied with drought stress. This result was consistent with previous studies $[24,26]$. This indicated that the two proteins (s1521 and s1368) might contribute to increasing the resistance to pre-harvest aflatoxin contamination in the resistant cultivar.

Trypsin inhibitor (s314), a constitutively expressed antifungal protein, was observed at high expression levels in resistant peanut cultivars [48] and maize lines $[49,41]$, but was at low or undetectable levels in susceptible cultivars and lines. However, in this study, there was no differential expression in both cultivars under well-watered and drought stress conditions, but downregulation of trypsin inhibitor was observed when challenged by $A$. flavus under drought stress in resistant cultivar. The true reason of down-regulation of trypsin inhibitor in our experiment remains unknown.

The functional distribution of unique and up-regulated proteins in resistant cultivar (YJ-1) also showed that most of the proteins affected were defense-related proteins, protein synthesis, and regulation of transcription. A. flavus infection in pre-harvested peanut seeds resulted in expression of six new proteins, no information of which was available in database. Three of them (spot s6256, s6258 and s6264) were detectable only in resistant cultivar, and three proteins (s1368, s1429 and s6169) were markedly up-regulated in resistant cultivar.

In addition, in this study, seven selected proteins for mRNA expression study showed up-regulation in both 
mRNA and protein expression, although it has been reported that the correlation between transcription and translation is known to be less than 50\% [50].

\section{Conclusion}

In conclusion, pre-harvest aflatoxin-resistance trait was characterized as a quantitative trait. Development of peanut cultivars with resistance to pre-harvest aflatoxin contamination would be a long-term selection program. This study reports the first proteome analysis to identify resistance-associated protein such as low molecular weight heat shock protein, Oso7g0179400, PII protein, CDK1, Oxalate oxidase, SAP domain-containing protein, RIO kinase, $\mathrm{L}$-ascorbate peroxidase, iso-Ara h3, $50 \mathrm{~S}$ ribosomal protein, $30 \mathrm{~S}$ ribosomal, which may be associated with resistance to pre-harvest aflatoxin contamination in peanut. More detailed analysis of the identified proteins is in progress to further characterize their possible functional roles in resistance to pre-harvested aflatoxin contamination.

\section{Methods}

Plants material and treatment

A resistant cultivar $\mathrm{YJ}-1$ and a susceptible cultivar YueyouY-7 were provided by Crops Research Institute, Guangdong Academy of Agricultural Sciences (GDAAS, China). A. flavus isolate As3.2890, a wild-type strain known to produce high levels of aflatoxin in peanut was provided by Institute of Microbiology, Chinese Academy of Sciences. All seeds were sterilized for $1 \mathrm{~min}$ in $70 \%$ ethanol, rinsed with sterile deionized water 3-4 times. Seeds were planted in plastic pots with sterilized soil and kept in the greenhouse at a temperature of $25-30^{\circ} \mathrm{C}$. Both resistant (YJ-1) and susceptible (Yueyou 7) cultivars were subjected to three treatments: (1) well-watered condition; (2) drought stress condition; (3) drought stress and $A$. flavus artificial inoculation condition. To simulate the late season drought, we watered the spots of the drought treatments with only $20 \mathrm{ml}$ of water per day starting on the $60^{\text {th }}$ day after sowing, while the spots of the well-watered treatments were watered normally. In A. flavus inoculation group, both cultivars were subjected to drought stress as group 2. In addition, A. flavus (As3.2890)-contaminated corn powder was sprayed to pots at 60 days after planting and covered with soil according to the method of Anderson et al (1996) [51]. All treatments were conducted simultaneously. The mature seeds were collected and immediately frozen in liquid nitrogen, and then stored in a freezer at $-80^{\circ} \mathrm{C}$.

\section{Measurement of aflatoxin B1}

Peanut seeds ( $5 \mathrm{~g}$ ) of all samples were sprayed with $95 \%$ alcohol and dried at $115^{\circ} \mathrm{C}$. The dried seeds were ground to powder, defatted with $20 \mathrm{ml}$ of $\mathrm{n}$-hexane, and then extracted with $25 \mathrm{ml}$ of aqueous methanol (1:1). Aflatoxin $B_{1}\left(A F B_{1}\right)$ extracts of all the samples were determined according to the manufacturer's directions of Aflatoxin $B_{1}$ quantization ELISA Kit (JSWSW, Jiangsu China).

\section{Seed total protein extraction}

The frozen peanut seeds ( $1 \mathrm{~g}$ ) of all samples were homogenized in a chilled mortar and ground to powder in liquid nitrogen and defatted with hexane according to Liang et al (2006b) [29]. The defatted samples were collected by centrifugation $\left(10,000 \times \mathrm{g}\right.$ for $10 \mathrm{~min}$ at $4{ }^{\circ} \mathrm{C}$ and the pellets were allowed to dry at room temperature. The dried pellets were further ground with pestle to a fine powder and re-suspended in $2 \mathrm{ml}$ of phenol for extraction of proteins based on a method modified from Sonia et al [52]. The supernatant was collected after centrifugation at $10,000 \times \mathrm{g}$ for $10 \mathrm{~min}$ at $4^{\circ} \mathrm{C}$ and precipitated with five volumes of ice-cold methanol plus 0.1 $\mathrm{M}$ ammonium acetate at $-20^{\circ} \mathrm{C}$ for $1 \mathrm{~h}$. Precipitated proteins were recovered by centrifugation at $10,000 \times \mathrm{g}$ for $10 \mathrm{~min}$ at $4^{\circ} \mathrm{C}$, and then washed five times with cold methanol, cold acetone and cold $80 \%$ acetone. The pellets were vacuum-dried and re-dissolved in $6 \mathrm{M}$ guanidinium chloride. Then $5 \mathrm{mM}$ TBP and $100 \mathrm{mM} 2-\mathrm{VP}$ (SIGMA, USA) were added to reduce and alkylate proteins and, after incubating for $90 \mathrm{~min}$ at room temperature, supernatant was collected by centrifuging at 10,000 $\times \mathrm{g}$ for $10 \mathrm{~min}$ at $4^{\circ} \mathrm{C}$. The supernatant was mixed with five volumes of ice-cold acetone: ethanol (1:1) to precipitate proteins at $-20^{\circ} \mathrm{C}$ for $10 \mathrm{~min}$. The precipitated proteins were recovered and washed twice with cold acetone/ethanol (1:1) and $80 \%$ acetone. The final pellets were air-dried and re-suspended in ProteomIQ ${ }^{\mathrm{Tm}} \mathrm{C} 7$ resuspension reagent (Proteome Systems, Inc., Australia) with a drop of ProteomIQ IEF tracking dye. These samples were used for 2-DE analysis.

\section{Two-dimensional gel electrophoresis (2-DE) and spot analysis}

The first-dimensional gel electrophoresis was performed using immobilized $\mathrm{pH}$ gradients (Proteome Systems Ltd, Sydney, Australia) according to the manufacturer's directions with some modifications. The dry $11 \mathrm{~cm} \mathrm{IPG}$ strips (pH5-8) (Proteome Systems Ltd) were rehydrated for $12 \mathrm{~h}$ with $200 \mu \mathrm{l}$ of protein sample, containing 0.3 $\mathrm{mg}$ of protein, at $14^{\circ} \mathrm{C}$. Isoelectric focusing (IEF) was performed at $20^{\circ} \mathrm{C}$ with PSL IsoElectrIQ ${ }^{\mathrm{TM}}$ electrophoresis equipment (Australian). The running conditions were: $1 \mathrm{~h}$ at $100 \mathrm{~V}, 8 \mathrm{~h}$ from $100 \mathrm{~V}$ to $10,000 \mathrm{~V}$ and $8 \mathrm{~h}$ at $10,000 \mathrm{~V}$. Current was limited $50 \mu \mathrm{A}$ per IPG gel strip. The focused strips were equilibrated immediately for $15 \mathrm{~min}$ in $10 \mathrm{ml}$ of sodium dodecyl sulfate (SDS) equilibration solution containing $50 \mathrm{mM}$ Tris-HCI buffers, 
pH8.8, 6 M urea, 2\% (wt/vol) SDS, 30\% (wt/vol) glycerol, 1\% (wt/vol) DTT and a drop of tracking dye at room temperature with shaking.

After equilibration, the second-dimension gel electrophoresis was carried out on $15 \%$ polyacrylamide-SDS gels $(20 \mathrm{~cm} \times 24 \mathrm{~cm} \times 0.1 \mathrm{~cm}$, width $\times$ length $\times$ thickness) at a constant voltage of $120 \mathrm{~V}$ for $5 \mathrm{~h}$ at $20^{\circ} \mathrm{C}$.

Preparative gels were fixed overnight in water containing $10 \%$ (vol/vol) acetic acid, 50\% (vol/vol) methanol, and stained with colloidal Coomassie Brilliant Blue G-250. All the stained gels were scanned and images were analyzed using Image Master 2 D Platinum 5.0 software (Amersham Biosciences). For each sample, gels were run in triplicate.

A comparison of the A. flavus-inducing variations between YJ-1 and Yuyou7 allowed the identifation of the induced protein spots that were present uniquely or at least four-fold up/down-regulated in the resistant cultivar compared to susceptible cultivar. For comparison of gels, the intensity data of individual protein spots present in each gel were normalized according to Image Master Software user manual. Intensity of all protein spots were interpreted by a percentage. Then the percent intensity volume (\% vol) of each individual spot (relative to the intensity volumes of all spots) was used for the comparative analysis with unpaired Student's t-test. P values less than 0.05 were considered statistically significant.

\section{MALDI-TOF MS analysis and protein identification}

The unique, down- or up-regulated protein spots in response to $A$. flavus infection in the resistant cultivar were cut and in-gel proteolysed with trypsin. The resulting peptides were analyzed by matrix-assisted laser desorption/ionization-time of flight mass spectrometry (MALDI-TOF MS) (WATERS Corporation, USA) at the Beijing Proteomics Research Center (BPRC, China). The list of peptide masses were transferred into the peptide mass fingerprint search program Mascot http://www. matrixscience.com as data file, and were compared with simulated proteolysis and fragmentation of known proteins in the NCBI-nr database. Search parameters in the program allowed for oxidation of methionine, carbamido-methylation of cysteine, one missed trypsin cleavage, and $0.2 \mathrm{Da}$ of mass accuracy for each peptide mass was allowed. Proteins with a MASCOT high score $(>60)$ were considered to be the target proteins. Proteins that were matched with a lower MASCOT score were considered tentative. In addition, the identified peptides were used for similarity searches against peanut gene indices generated in our laboratory using tBLASTn algorithm.

\section{Real Time RT-PCR analysis}

Total RNA was isolated from peanut seeds using Trizol reagent (Invitrogen, Carlsbad, CA), and genomic DNA was removed by adding RNase-free DNase I (Takara). And then, the RNA samples were purified with the RNeasy Cleanup Kit (Qiagen). Nano drop ND-1000 Spectrophotometer and agarose gel electrophoresis was performed to test RNA quality as described by Aranda, et al (2009) [53]. For all the samples, $4 \mu \mathrm{g}$ of total RNA was converted to cDNA using PrimeScript II $1^{\text {st }}$ Strand cDNA Synthesis kit (Takara) according to the manufacturer's protocols. Quantitative real-time RT-PCR was performed with SYBR ${ }^{\mathrm{R}}$ Premix Ex Taq ${ }^{\mathrm{Ts}} \mathrm{II}$ kit (Takara) and a LightCycler 480 instrument (Roche) equipped with Light- Cycler Software Version 1.5 (Roche) based on the manufacturer's instructions [54]. Amplifications reactions were carried out in a total volume of $20 \mu \mathrm{l}$. PCR cycling was: $95^{\circ} \mathrm{C}$ for $10 \mathrm{~s}$, followed by 45 cycles of $95^{\circ} \mathrm{C}$ for $10 \mathrm{~s}, 60^{\circ} \mathrm{C}$ for $10 \mathrm{~s}$, and $72^{\circ} \mathrm{C}$ for $20 \mathrm{~s}$. Data collection was performed during the annealing phase of the each amplification. Then processing of the melting curve was from 62 to $95^{\circ} \mathrm{C}$ with reading the intensity of fluorescence every 0.2. All protein-specific primers were designed using the Primer Version 5.0 (PREMIER Biosoft Intern ational) and listed in Table 4. The actin gene from peanut seed was used as an internal control for

Table 4 Primers used for real time RT-PCR of differentially expressed peanut seed proteins in different treatments

\begin{tabular}{|c|c|c|c|c|}
\hline Spot NO. & Protein description & forward primer(5'-3') & reverse primer(5'-3') & Length (bp) \\
\hline 56107 & Low molecular weight HSP precursor & GCTGGACTTCGTCGTGGTTG & TGGTCAGGGTGTTCTGCTCC & 121 \\
\hline S6256 & Os07g0179400 & CCGCTCAAGATGATCCCATG & ACTGTGCTGAAGCGGTGAGG & 129 \\
\hline S6258 & PIl protein & ATCGGAACGTGGTTCTCACG & GCCTAAGAATGGCTTCCGCT & 132 \\
\hline S6264 & CDKD1 & GTGCTTCAGCGATTCAACGA & GAGGGATCCGGGTCTGTCAT & 131 \\
\hline S6278 & Oxalate Oxidase & GTTCCATTGTAACAGGAGCCA & TGAGTCCACCTGGGGCATA & 123 \\
\hline S6503 & SAP domain-containing protein & CACCAGAGGGCCAGCATATT & GATCCCTCGGTTCCATCCTT & 115 \\
\hline S1314 & Trypsin inhibitor & AAAATGCGTGCCAGTTCCAG & GGAGGACTAAGCGCGAGAGG & 141 \\
\hline S1368 & RIO kinase & TGGCTTGACTCCAAGGACGA & GAGAGAGGCTGGAGGGTGGA & 125 \\
\hline S1419 & Iso-Ara h3 & TCCAATGCTCCCCTCGAGAT & TGGGTCGTCCTGCCCTACTT & 159 \\
\hline S1429 & 50 S ribosomal protein L22 & TCTCTCTCAATTCTCGCCGC & CACGAATGTGGTGCGTGAAC & 117 \\
\hline S1521 & L-ascorbate peroxidase 1 & TGGCCGGTGTAGTTGCTGTT & CCCATAGCCTTGCCAAACAC & 154 \\
\hline S6169 & Putative $30 \mathrm{~S}$ ribosomal protein $\mathrm{S} 9$ & AGGAGGCGGTGTTTCAGGTC & TGTCAGGAAGCCAGCGTTTC & 112 \\
\hline
\end{tabular}


calculating relative transcript abundance. The amplicon of this gene is $104 \mathrm{bp}$ and the primers are: forward (5'GTTCC ACTAT GTTCC CAGGC A-3') and reverse (5'-CTTCC TCTCT GGTGG TGCTA CA-3'). All realtime PCR reactions were technically repeated three times. The relative quantification of RNA expression was calibrated using formula $2^{-\Delta \Delta \mathrm{Ct}}$ method [55].

\section{Additional material}

Additional file 1: Reproducibility of two-dimensional gels Additional file 2: Summary of differential expression of proteins in Yueyou7 and YJ-1 in three treatments

\section{Acknowledgements}

This research was funded by a grant from National High Technology Research Development Project (863) of China (No 2006AA0Z156), Science Foundation of Guangdong province (No07117967) and supported by the earmarked fund for Modern Agro-industry Technology Research System (nycycx-19).

\section{Author details}

${ }^{1}$ Gguangdong Key Lab of Biotechnology for Plant Development, College of Life Science, South China Normal University, Guangzhou 510631, China. ${ }^{2}$ Crops Research Institute, Guangdong Academy of Agricultural Sciences, Guangzhou 510640, China.

\section{Authors' contributions}

All authors read and approved the final manuscript. TW participated in conceiving the study, material preparation, sequence analysis and drafting the manuscript. EZ carried out the 2-D analysis. XC participated in conceiving the study, designing the real time PCR primers and data analysis. $\mathrm{LL}$ participated in conceiving the study and material preparation. $\mathrm{XL}$ participated in conceiving the study, data analysis and drafting the manuscript.

Received: 31 August 2010 Accepted: 30 November 2010 Published: 30 November 2010

\section{References}

1. Liang XQ, Luo M, Guo BZ: Resistance mechanisms to Aspergillus flavus infection and aflatoxin contamination in peanut (Arachis hypogaea). Journal of plant pathology 2006, 5(1):115-124.

2. Guo BZ, Chen ZY, Lee RD, Scully BT: Drought stress and preharvest aflatoxin contamination in agricultural commodity: genetics, genomics and proteomics. Journal of Integrative Plant Biology 2008, 50(10):1281-1291.

3. Passone MA, Ruffino M, Ponzio V, Resnik S, Etcheverry MG: Postharvest control of peanut Aspergillus section Flavi populations by a formulation of food-grade antioxidants. International Journal of Food Microbiology 2009, 131:211-217.

4. Cole RJ, Hill RA, Blankenship PD, Sanders TH, Garren KH: Influence of irrigation and drought stress on invasion by Aspergillus flavus of corn kernels and peanut pods. Dev Ind Microbiol 1982, 23:229-236.

5. Cole RJ, Sanders TH, Hill RA, Blankenship PD: Mean geocarposphere temperatures that induce preharvest aflatoxin contamination of peanuts under drought stress. Mycopathologia 1985, 91:41-46.

6. Blankenship PD, Cole RJ, Sanders TH, Hill RA: Environmental plot facility with manipulable soil temperature. Oleagineux 1983, 38(11):615-620.

7. Blankenship PD, Cole RJ, Sanders TH, Hill RA: Effect of geocarposphere temperature on pre-harvest colonization of drought-stressed peanuts by Aspergillus flavus and subsequent aflatoxin contamination. Mycopathologia 1984, 85:69-74.

8. Hill RA, Blankenship PD, Cole RJ, Sanders TH: The effects of soil moisture and temperature on preharvest invasion of peanuts by the Aspergillus flavus group and subsequent aflatoxin development. Appl Environ Microbiol 1983, 45:628-633.

9. Wilson DM, Stansell JR: Effect of irrigation on aflatoxin contamination of peanut pods. Peanut Science 1983, 10:54-56

10. Cole RJ, Sanders TH, Dorner JW, Blankenship PD: Environmental conditions required to induce preharvest aflatoxin contamination of groundnuts: summary of six years' research. Aflatoxin contamination of groundnuts ICRISAT, Patancheru, India; 1989, 279-287.

11. Sanders TH, Cole RJ, Blankenship PD, Dorner JW: Aflatoxin contamination of peanuts from plants drought stressed in pod or root zones. Peanut Science 1993, 20(1):5-8.

12. Anderson WF, Holbrook CC, Wilson DM, Matheron ME: Evaluation of preharvest aflatoxin contamination in several potentially resistant peanut cultivars. Peanut Science 1995, 22:29-32.

13. Blankenship PD, Cole1 RJ, Sanders TH: Comparative susceptibility of four experimental peanut lines and the cultivar florunner to preharvest matoxin contamination. Peanut Science 1985, 13:70-73.

14. Holbrook CC, Kvien CK, Ruckers KS, Wilson DM, Hook JE: Preharvest aflatoxin contamination in drought tolerant and intolerant peanut cultivars. Peanut Science 2000, 21:20-22.

15. Kisyombe CT, Beute MK, Payne GA: Field evaluation of peanut cultivars for resistance to infection by Aspergillus parasiticus. Peanut Science 1985, 12:12-17.

16. Mehan VK, McDonald D, Ramakrishna N, Williams JH: Effect of cultivar and date of harvest on infection of peanut seed by Aspergillus flavus and subsequent contamination with aflatoxin. Peanut Science 1986, 13:46-50.

17. Mehan VK, McDonald D, Rajagopalan K: Resistance of peanut cultivars to seed infection by Aspergillus flavus in field trials in India. Peanut Science 1987, 14:17-21.

18. Mehan VK, Rao RCN, McDonald D, Williams JH: Management of drought stress to improve field screening of peanuts for resistance to Aspergillus flavus. Phytopathology 1988, 78:659-663.

19. Waliyar F, Hassan H, Bonkoungou S, Bose JP: Sources of resistance to Aspergillus flavus and aflatoxin contamination in groundnut cultivars in west Africa. Plant Dis 1994, 78:704-708.

20. Will ME, Holbrook CC, Wilson DM: Evaluation of field inoculation techniques for screening peanut cultivars for reaction to preharvest $A$. flavus group infection and aflatoxin contamination. Peanut Science 1994, 21:122-125.

21. Payne GA, Brown MP: Genetics and physiology of aflatoxin biosynthesis Annu Rev Phytopathol 1998, 36:329-362.

22. Luo M, Brown RL, Chen ZY, Cleveland TE: Host genes involved in the interaction between Aspergillus flavus and maize. Toxin Reviews 2009, 28(2-3):118-128.

23. Domer JW, Cole RJ, Sanders TH, Blankenship PD: Interrelationship of kerne water activity, soil temperature, maturity, and phytoalexin production in pre-harvest aflatoxin contamination of drought-stressed peanuts. Mycopathologia 1989, 105:117-128.

24. Wotton HR, Strange RN: Circumstantial evidence for phytoalexin involvement in the resistance of peanuts to Aspergillus flavus. J Gen Microbiol 1985, 131:487-494.

25. Luo M, Liang XQ, Dang P, Holbrook CC, Bausher MG, Lee RD, Guo BZ Microarray-based screening of differentially expressed genes in peanut in response to Aspergillus parasiticus infection and drought stress. Plant Science 2005, 169:695-703.

26. Chen ZY, Brown RL, Damann KE, Cleveland TE: Identification of maize kernel endosperm proteins associated with resistance to aflatoxin contamination by Aspergillus flavus. Phytopathology 2007, 97(9):1094-1103.

27. Chen ZY, Brown RL, Guo BZ, Menkir A, Cleveland TE: Identifying aflatoxin resistance-related proteins/genes through proteomics and RNAi gene silencing. Peanut Science 2009, 36:35-41.

28. Zhou GY, Liang XQ, Li YC, Li SX, Li SL: Genetic analysis of main agronomic traints in resistant and susceptible peanut cultivars to Aspergilluse flavus infection. Peanut Science and Technology 1999, , supplement: 140-143.

29. Liang XQ, Luo M, Holbrook CC, Guo BZ: Storage protein profiles in Spanish and runner market type peanuts and potential markers. BMC Plant Biology 2006, 6:1-24.

30. Kottapalli KR, Payton P, Rakwal R, Agrawal GK, Shibato J, Burow M, Puppala N: Proteomics analysis of mature seed of four peanut cultivars using two-dimensional gel electrophoresis reveals distinct differential 
expression of storage, anti-nutritional, and allergenic proteins. Plant Science 2008, 175:321-329.

31. Ohyanagi H, Tanaka T, Sakai H, Shigemoto Y, Yamaguchi K, Habara T, Fujii Y, Antonio BA, Nagamura Y, Imanishi T, Ikeo K, Itoh T, Gojobori T, Sasaki T: The Rice Annotation Project Database (RAP-DB): hub for Oryza sativa ssp. japonica genome information. Nucleic Acids Res 2006, 34:741-714.

32. Shimotohno A, Umeda-Hara C, Bisova K, Uchimiya H, Umeda M: The plantspecific kinase CDKF; 1 is involved in activating phosphorylation of cyclin-dependent kinase-qctivating kinases in arabidopsis. The Plant Cell 2004, 16:2954-2966.

33. Lane BG, Dunwell JM, Rag JA, Schmitt MR, Cumin AC: Germin, a protein marker of early plant development, is an oxalate oxidase. The Journoa of Biological chemistry 1993, 68(17):12239-12242.

34. Rollins JA: The Sclerotinia sclerotiorum pac1 gene Is required for sclerotial development and virulence. MPMI 2003, 16(9):785-795.

35. Livingstone DM, Hampton JL, Phipps PM, Grabau EA: Enhancing resistance to sclerotinia minor in peanut by expressing a barley oxalate oxidase gene1. Plant Physiology 2005, 137:1354-1362.

36. Manosalva PM, Davidson RM, Liu B, Zhu XY, Hulbert SH, Leung H, Leach JE: A germin-like protein gene family functions as a complex quantitative trait locus conferring broad-spectrum disease resistance in rice. Plant Physiology 2009, 149:286-296.

37. Banerjee J, Maiti MK: Functional role of rice germin-like protein1 in regulation of plant height and disease resistance. Biochemical and Biophysical Research Communications 2010, 394:178-183.

38. Sugiyama K, Hayakawa T, Kudo T, Ito T, Yamaya T: Interaction of Nacetylglutamate kinase with a PII-like protein in rice. Plant Cell Physiol 2004, 45:1768-1778.

39. Ferrario-Me'ry S, Besinb E, Pichonc O, Meyera C, Hodgesb M: The regulatory PII protein controls arginine biosynthesis in Arabidopsis. FEBS Letters 2006, 580:2015-2020.

40. Zhu B, Chen TH, Li PH: Expression of three osmotine-like protein genes in response to osmotic stress and fungal infection in potato. Plant $\mathrm{Mol}$ Biol 1995, 28:17-26

41. Chen ZY, Brown RL, Damann KE, Cleveland TE: Identification of unique or elevated levels of kernel proteins in aflatoxin-resistant maize cultivars through proteome analysis. Phytopathology 2002, 92(10):1084-1094.

42. Vagner S, Galy B, Pyronnet S: Attracting the translation machinery to internal ribosome entry sites. EMBO report 2001, 2(10):893-898.

43. Rizhsky L, Liang H, Shuman J, Shulaev V, Davletova S, Mittler R: When defense advanced research projects networkefense pathways Collide: the response of arabidopsis to a combination of drought and heat stress. Plant Physiology 2004, 134:1-14.

44. Mittler R, Zilinskas BA: Regulation of pea cytosolic ascorbate peroxidase and other antioxidant enzymes during the progression of drought stress and following recovery from drought. The Plant Journal 1994, 5(3):397-405

45. Davletova S, Rizhsky L, Liang H, Zhong SQ, Oliver DJ, Coutu J, Shulaev V Schlauch K, Mittlera R: Cytosolic ascorbate peroxidase 1 is a central component of the reactive oxygen gene network of arabidopsis. The Plant Cell 2005, 17:268-281.

46. Yoshioka K, Matsushita Y, Kasahara M, Konagaya K, Nyunoya H: Interaction of tomato mosaic virus movement protein with tobacco RIO kinase. Mol Cells 2004, 17(2):223-239.

47. LeBlanc NL, Wlodawer A: The RIO kinases: an atypical protein kinase family required for ribosome biogenesis and cell cycle progression. Biochimica et Biophysica Acta 2005, 1754:14-24

48. Liang $X Q$, Pan $R C$, Zhou GY: Relationship of trypsin inhibitor in peanut seed and resistance to Aspergillus flavus invasion. Acta Agronomica Sinica 2003, 29(2):295-299.

49. Chen ZY, Brown RL, Lax AR, Guo BZ, Cleveland TE, Russin JS: Resistance to Aspergillus flavus in corn kernels is associated with a 14-kDa protein. Phytopathology 1998, 88:276-281.

50. King HC, Sinha AA: Gene expression profile analysis by DNA microarrays promise and pitfalls. JAMA 2001, 286:2280-2288.

51. Anderson WF, Holbrook CC, Wilson DM: Development of greenhouse screening for resistance to Aspergillus parasiticus infection and preharvest aflatoxin contamination in peanut. Mycopathologia 1996, 135:115-118.
52. Gómez-Vidal S, Tena M, Lopez-Llorca LV, Salinas J: Protein extraction from Phoenix dactylifera $\mathrm{L}$. leaves, a recalcitrant material, for two dimensional electrophoresis. Electrophoresis 2008, 29:448-456.

53. Aranda RIV, Dineen SM, Craig RL, Guerrieri RA, Robertson JM: Comparison and evaluation of RNA quantification methods using viral, prokaryotic, and eukaryotic RNA over a 104 concentration range. Analytical Biochemistry 2009, 387:122-127.

54. Alos E, Roca M, Iglesias DJ, Minguez-Mosquera MI, Damasceno CMB, Thannhauser TW: An evaluation of the basis and consequences of a staygreen mutation in the navel negra citrus mutant using transcriptomic and proteomic profiling and metabolite analysis. Plant Physiology 2008, 147:1300-1315

55. Livak KJ, Schmittgen TD: Analysis of relative gene expression data using real-time quantitative $P C R$ and the $2-\Delta \Delta C$ t method. Methods 2001 , 25:402-408.

doi:10.1186/1471-2229-10-267

Cite this article as: Wang et al:: Identification of seed proteins associated with resistance to pre-harvested aflatoxin contamination in peanut (Arachis hypogaea L). BMC Plant Biology 2010 10:267.

\section{Submit your next manuscript to BioMed Central and take full advantage of:}

- Convenient online submission

- Thorough peer review

- No space constraints or color figure charges

- Immediate publication on acceptance

- Inclusion in PubMed, CAS, Scopus and Google Scholar

- Research which is freely available for redistribution

Submit your manuscript at www.biomedcentral.com/submit
Biomed Central 